Revista de Metalurgia 52(1)

January-March 2016, e064

ISSN-L: 0034-8570

doi: http://dx.doi.org/10.3989/revmetalm.064

\title{
Direct measurement of the adsorption kinetics of 2-Mercaptobenzothiazole on a microcrystalline copper surface
}

\author{
Jorge A. Ramírez-Cano ${ }^{\bowtie}$, Lucien Veleva \\ Research and Advanced Studies Centre of the National Polytechnic Institute of México, (CINVESTAV-Unidad Mérida), \\ Department of Applied Physics, Antigua Carretera a Progreso km. 6, Cordemex, 97310 Mérida-Yucatán, México \\ Corresponding author: iqramirez59@gmail.com, ramirezj@mda.cinvestav.mx
}

Submitted: 4 December 2015; Accepted: 15 January 2016; Available on-line: 7 March 2016

\begin{abstract}
The adsorption on copper of 2-Mercaptobenzothiazole (2-MBT), a heterocyclic compound member of the tiazole family, has been investigated at different concentrations $\left(1 \times 10^{-1}\right.$ to $\left.1 \times 10^{-6} \mathrm{M}\right)$ in water, employing the Electrochemical Quartz Crystal Microbalance (EQCM). The frequency response over time was obtained for each concentration, showing a defined exponential behavior at higher concentrations $\left(1 \times 10^{-1}, 1 \times 10^{-2}\right.$ and $\left.1 \times 10^{-3} \mathrm{M}\right)$, which was fitted to the Langmuir adsorption isotherm with a good correlation coefficients $\left(R^{2}=0.91\right.$ to 0.98$)$. Surface coverage $(\theta)$ was calculated and found to be in the order of 0.50 to 0.01 for 2-MBT high concentrations. The free energy of adsorption was $\Delta G_{a d s}=-5.59 \mathrm{~kJ} \mathrm{~mol}^{-1}$, corresponding to physisorption process, probably of electrostatic nature of the interaction between 2-MBT and copper surface in aqueous solution.
\end{abstract}

KEYWORDS: EQCM; Free energy of adsorption; Langmuir isotherm; 2-MBT

\begin{abstract}
Citation / Cómo citar este artículo: Ramírez-Cano, J.A., Veleva, L. (2016) "Direct measurement of the adsorption kinetics of 2-Mercaptobenzothiazole on a microcrystalline copper surface". Rev. Metal. 52 (1): e664. doi: http://dx.doi. org/10.3989/revmetalm.064.

RESUMEN: Medición directa de la cinética de adsorción del 2-Mercaptobenzotiazol en una superficie micro cristalina de cobre. En el presente trabajo se ha investigado la adsorción del 2-Mercaptobenzotiazol (2-MBT) en cobre, un compuesto heterocíclico miembro de la familia de los tiazoles, en solución acuosa a diferentes concentraciones $\left(1 \times 10^{-1}\right.$ a $\left.1 \times 10^{-6} \mathrm{M}\right)$, empleando la Balanza Electroquímica de Cristal de Cuarzo (BECC). Se midió y analizó el cambio de frecuencia con respecto al tiempo para cada concentración, mostrando un comportamiento exponencial definido en el rango de concentraciones altas $\left(1 \times 10^{-1}, 1 \times 10^{-2}\right.$ y $\left.1 \times 10^{-3} \mathrm{M}\right)$, los cambios de frecuencia registrados se ajustaron usando la isoterma de adsorción de Langmuir obteniendo buenos coeficientes de correlación $\left(R^{2}=0,91\right.$ a 0,98$)$. Se calculó también la fracción de superficie recubierta y se halló que se encuentra en el orden de 0,50 a 0,01 para las concentraciones altas de 2-MBT. La energía libre de adsorción calculada fue de $\Delta G_{a d s}=-5,59 \mathrm{~kJ} \mathrm{~mol}^{-1}$, lo cual corresponde a un proceso de fisisorción.
\end{abstract}

PALABRAS CLAVE: BECC; Energía libre de adsorción; Isoterma de Langmuir; 2-MBT

Copyright: (C) 2016 CSIC. This is an open-access article distributed under the terms of the Creative Commons Attribution-Non Commercial (by-nc) Spain 3.0 License.

\section{INTRODUCTION}

Corrosion is a serious problem in many fields of industry, destroying the metal components in structures, electronic devices, vehicles, etc., as a consequence has a great impact on the economy of any country. Thus, the protection of metals and alloys is of paramount importance for large industrial conglomerates and the search for effective means to prevent corrosion is a very active area.

Copper and its alloys are extensively used in industrial applications, ranging from construction 
to electronics, this metal is present in almost every aspect of modern life (Davis, 2001). Copper is a relatively resistant metal in atmospheric neutral environments, in the absence of chlorides and $\mathrm{SO}_{2}$, protected by the formed copper patina $\left(\mathrm{Cu}_{2} \mathrm{O}\right)$. However, it is susceptible to corrosion in aggressive media, when the patina is converted to other corrosion products (Allam et al., 2009). There are several methods to prevent metal corrosion and one of them is the use of inhibitors, organic or inorganic (Aballe et al., 1997).

Organic inhibitors are compounds that, applied in very small concentrations, are capable of effectively reduce the corrosion rate. Many of them are heterocyclic compounds consisting of a $\pi$-system and/or containing $\mathrm{O}, \mathrm{N}$, or $\mathrm{S}$ heteroatoms (Schmitt, 1984; Quraishi and Jamal, 2001; Godínez et al., 2003; Antonijevic and Petrovic, 2008; Khaled et al., 2009; Behpour and Mohammadi, 2012; Pan et al., 2013; Finšgar and Merl, 2014; Winkler et al., 2014; Jakeria et al., 2015). Among these compounds those of the azole group, containing nitrogen and/or sulphur, are considered as effective corrosion inhibitors for copper (Marconato et al., 1998; Subramaninan and Lakshminarayanan, 2002; Finšgar and Merl, 2014; Winkler et al., 2014). Despite the fact that organic inhibitors have been extensively investigated in the last decades, their inhibition mechanism is usually unknown (Trabanelli and Carassiti, 1970; Chadwick and Hashemi, 1979; Zhang et al., 2007; Morales-Gil et al., 2014). It is generally accepted that inhibition is achieved by the formation of a protective film formed by adsorbed inhibitor molecules on the metal surface (Marconato et al., 1998; Subramaninan and Lakshminarayanan, 2002; Godínez et al., 2003; Solmaz et al., 2011; Kazansky et al., 2012), which acts as a barrier between the aggressive media and the metal surface.

However, the kinetics of the formation process of this protective film remains unresolved. There are several techniques that can be used to study the adsorption process of organic molecules on metal substrates.

The most notable techniques are: measurement of mass change, using the electrochemical quartz crystal micro-balance (EQCM), measurement of contact angle, ellipsometry, reflectance absorption infrared spectroscopy (RA-IRS), surface plasmon resonance (SPR), electrochemical impedance spectroscopy (EIS) and atomic force microscopy (AFM) (Subramanian and Lakshminarayanan, 2000).

The EQCM is a valuable tool that enables the acquisition of relevant data about the adsorption of chemical species (molecules or ions) on metallic substrates in the microscale and characterization of their adsorption kinetics (Eickes et al., 2000; Telegdi et al., 2000). It consists of a quartz resonator, sandwiched between two metal electrodes, these electrodes produce an oscillating electric field, causing

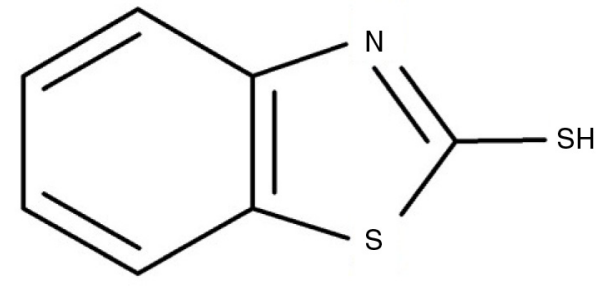

FIGURE 1. Schematic molecular structure of 2-MBT.

vibrational motion of the crystal at its fundamental frequency. The frequency is sensitive to the mass change of the resonator and when adsorption or desorption of mass occurs, a frequency shift is detected. Thus, adsorption will be registered as a frequency decrease, while desorption will produce a frequency increase.

The aim of this work is to enlarge the information about the adsorption of 2-Mercaptobenzothiazole (2-MBT, $\mathrm{C}_{7} \mathrm{H}_{5}-\mathrm{NS}_{2}$ ) see Fig. 1, a member of the azole's group, used as corrosion inhibitor for copper (Winkler et al., 2014). The research was carried out employing the EQCM to obtain the frequency response over time, the adsorption isotherm, the fraction of surface coverage and the free energy of 2-MBT adsorption.

\section{MATERIALS AND METHODS}

Commercially available reactive grade (96\%) Aldrich 2-Mercaptobenzothiazole, was used without further purification to prepare solutions with distilled water. The concentration range of 2-MBT was $1 \times 10^{-6}$ to $1 \times 10^{-1} \mathrm{M}(\mathrm{pH}=6.5)$.

The EQCM working electrodes are manufactured by Gamry Instruments and they consist of AT-cut quartz crystals coated with $\mathrm{Cu}$, having an active area of $0.205 \mathrm{~cm}^{2}$ and a sensitivity factor $C_{f}$ of $226 \mathrm{~Hz} \mathrm{~cm}^{2} \mu \mathrm{g}^{-1}$, having a fundamental frequency of $10 \mathrm{MHz}$. All experiments were carried out in a Gamry Teflon Cell, specifically designed to be used with the EQCM working electrodes.

\subsection{Frequency response over time}

During 2-MBT adsorption process, conducted at $22{ }^{\circ} \mathrm{C}, \mathrm{EQCM} 10 \mathrm{M}$ Gamry frequency monitor was used to record the frequency response during 3600 seconds, inside a Gamry Vista Shield Faraday Cage.

\subsection{Adsorption isotherm}

Frequency variations $(\Delta f)$ detected by the EQCM are due to several contributions:

$\Delta f=\Delta f_{d}+\Delta f_{m}+\Delta f_{a}+\Delta f_{x}$ 
where $\Delta f_{d}$ is the portion of the frequency shift related to viscous damping; $\Delta f_{m}$ is caused by adsorbed mass; $\Delta f_{a}$ is surface stress and $\Delta f_{x}$ is caused by energy dissipation.

As can be seen the frequency shift (Eq. 1) is the result of a very complex process and it does not depend of only the mass change. Therefore, obtaining surface coverage information from frequency variation data is at least problematic. However, the time dependence of this frequency response is the result of the formation of an adsorbed monolayer, therefore the time domain measurements are sensitive to adsorption kinetics of the monolayer and thus, surface coverage information can be extracted from frequency response over time data (Karpovich and Blanchard, 1994). The obtained frequency shift data were fitted to the Langmuir isotherm (Langmuir, 1918; Karpovich and Blanchard,1994; Subramanian and Lakshminarayanan, 2000; Marczewski, 2010; Haerifar and Azizian, 2013):

$\theta\left(t-t_{0}\right)=K^{\prime}\left[1-e^{\left(k_{m}\right)\left(t-t_{0}\right)}\right]$

where $K^{\prime}=C\left[C+(k d)\left(k a^{-1}\right)\right]^{-1} ; \theta$ is the surface coverage; $t$ is time; $t_{0}$ is the diffusion time and $k_{m}$ is the rate constant of adsorption and it is related to the adsorption and desorption constants by the following relation:

$k_{m}=k_{a} C+k_{d}$

being $k_{a}$ the adsorption constant, $k_{d}$ the desorption constant and $C$ the inhibitor concentration. A linear fit of $k_{m}$ vs $C$ gives $k_{a}$ as the slope of the line and $k_{d}$ as the intercept.

\subsection{Fraction of surface coverage and free energy of adsorption}

Surface coverage $(\theta)$ was calculated using the following equation:

$\Theta=C\left[C+K_{e q}^{-1}\right]^{-1} \mid K_{e q}=\left(k_{a}\right)\left(k_{d}\right)^{-1}$

where $C$ is the inhibitor concentration and $K_{e q}$ is the equilibrium constant (Karpovich and Blanchard, 1994). The free energy of adsorption $\Delta G_{a d s}$ was found directly from equilibrium constant data, using the thermodynamic relation (Karpovich and Blanchard, 1994):

$\Delta G_{a d s}=-R T \ln K_{e q}$

where $R$ is the ideal gas constant and $T$ is temperature.

\section{RESULTS AND DISCUSSIONS}

\subsection{Frequency response over time}

The frequency response for the adsorption of 2-MBT on copper is shown in Figs. 2-7. The curves were obtained inverting the Y-axis $(-\Delta f$ vs $t)$. The observed frequency shift follows a well-defined exponential law, when 2-MBT concentration was in the range of $1 \times 10^{-1}$ to $1 \times 10^{-2} \mathrm{M}$ (Fig. 2 and Fig. 3).

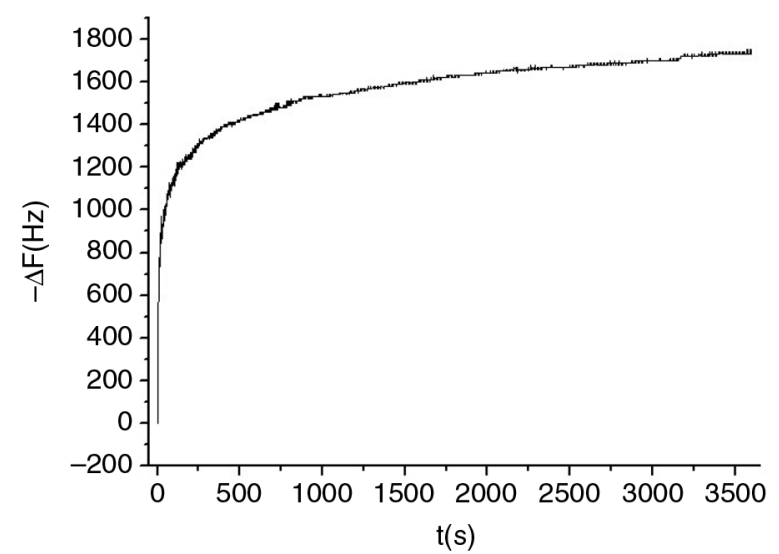

FIGURE 2. Frequency response over time of $1 \times 10^{-1} \mathrm{M} 2$-MBT on copper.

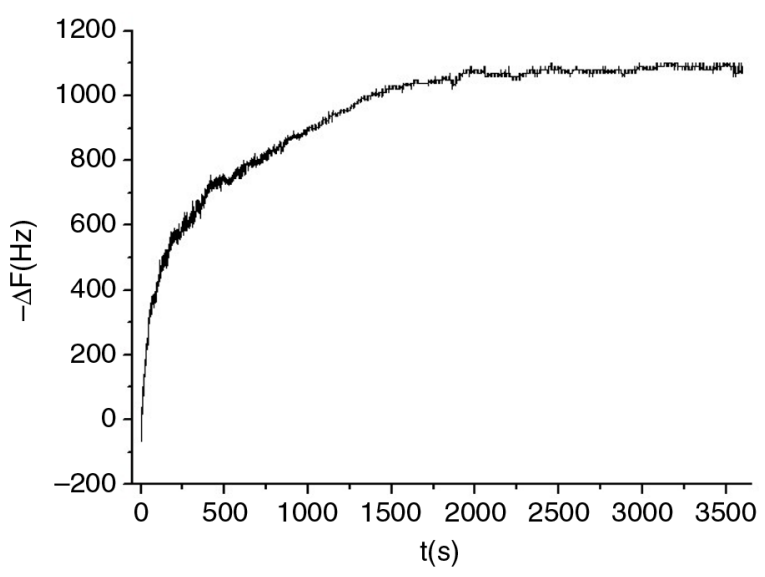

FIGURE 3. Frequency response over time of $1 \times 10^{-2} \mathrm{M} 2-\mathrm{MBT}$ on copper.

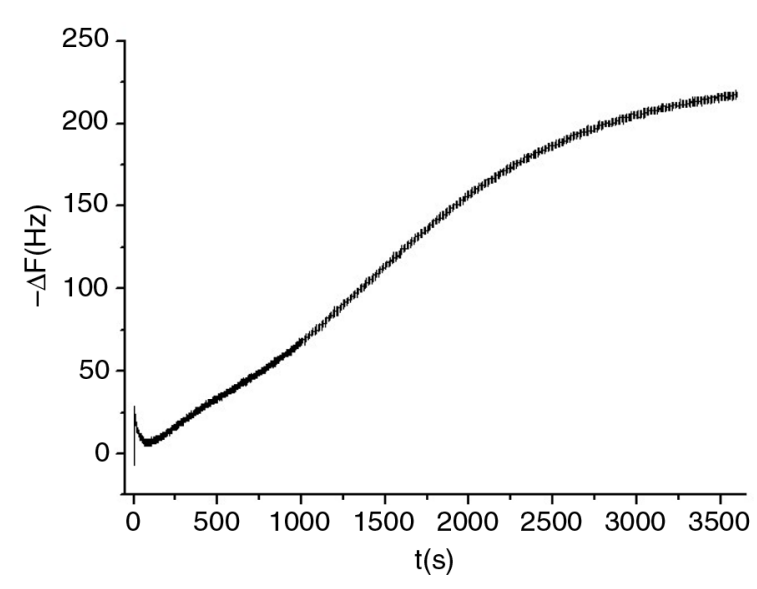

FIGURE 4. Frequency response over time of $1 \times 10^{-3} \mathrm{M} 2$-MBT on copper. 


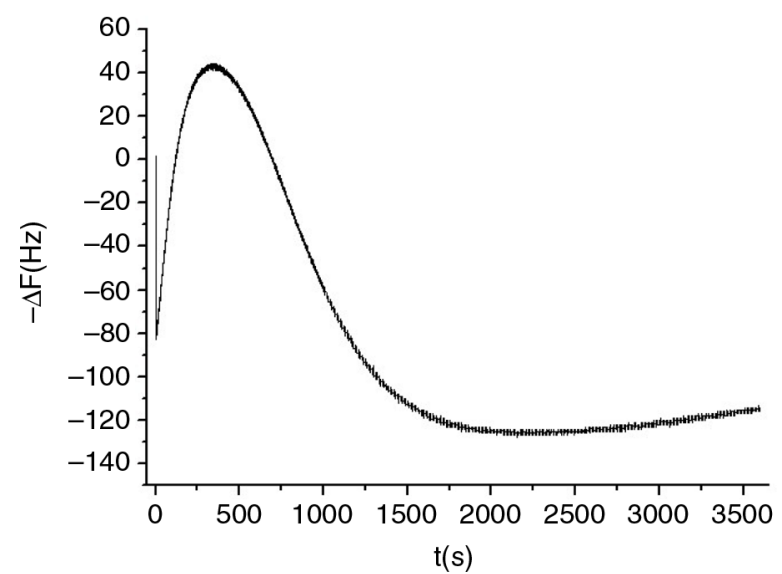

FIGURE 5. Frequency response over time of $1 \times 10^{-4} \mathrm{M} 2$-MBT on copper.

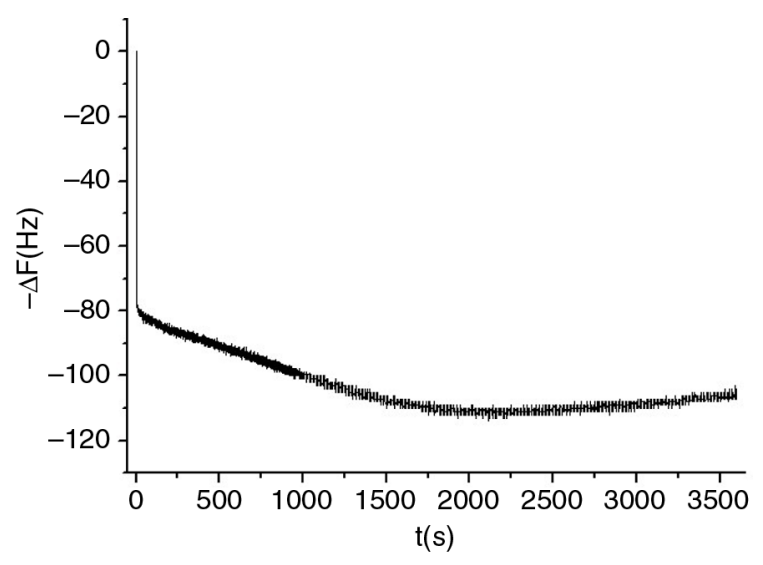

Figure 6. Frequency response over time of $1 \times 10^{-5} \mathrm{M} 2$-MBT on copper.

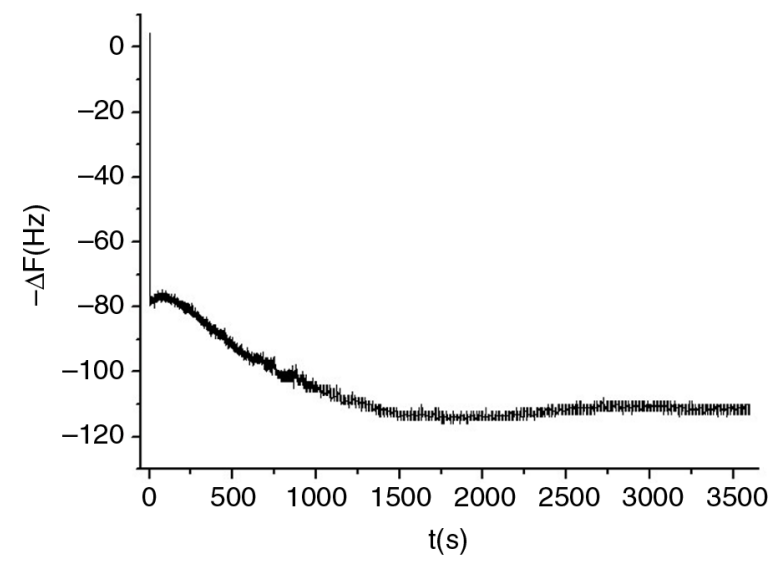

Figure 7. Frequency response over time of $1 \times 10^{-6} \mathrm{M} 2$-MBT on copper.

The exponential behavior starts decaying at 2-MBT concentration $1 \times 10^{-3} \mathrm{M}$ (Fig. 4).

At $1 \times 10^{-2}$ to $1 \times 10^{-6} \mathrm{M} 2$-MBT concentrations (Fig. 3 to Fig. 7), an initial desorption process was observed. This desorption process was attributed to the substitution of water molecules by 2 -MBT molecules on the copper surface, according to the model described by Kern and Landolt (2001).

Desorption region increases as the concentration of 2-MBT decreases. It is clearly visible that a three step process takes place. In the first step 2-MBT molecules reach the metallic surface and force water molecules to desorb (initial desorption).

The second step is the adsorption of 2-MBT molecules at the active copper sites that are now vacant, due to the water desorption. It is considered that initially 2-MBT molecule is adsorbed in the metal surface through the exo-sulfur atom (Oshawa and Süetaka, 1979; Subramaninan and Lakshminarayanan, 2002; Kazansky et al., 2012; Ramenzanzadeh et al., 2014) this fact is possible because 2-MBT molecules exhibit the thiolthione tautomerism (Oshawa and Süetaka, 1979; Ramenzanzadeh et al., 2014), in the range of $\mathrm{pH}$ of 3 to 9 (Jing et al., 2013), which leads to an anionic form of 2-MBT (Winkler et al., 2014) (Fig. 8).

The final step of the adsorption is the rearranging of 2-MBT molecules on the metal surface, as proposed in (Kokalj et al., 2010), for molecules containing bencene rings. This molecule rearranging gives place to more water desorption, leaving unoccupied active sites on the metal surface, in the vicinity of the already adsorbed 2-MBT molecules.

Due to this fact, the new active sites are rapidly occupied by other inhibitor molecules available in the solution.

However, when 2-MBT concentration is too low (i.e., $1 \times 10^{-4}$ to $1 \times 10^{-6} \mathrm{M}$ ), there are not enough molecules to adsorb and compensate the mass loss, due to water desorption and thus, the resulting frequency response corresponds only to a desorption process (Fig. 5 to Fig. 7).

At concentration higher than $1 \times 10^{-4} \mathrm{M} 2$-MBT (Fig. 2 to Fig. 4), there are enough inhibitor molecules to take the vacant sites left by water and therefore, no subsequent desorption is observed.

\subsection{Adsorption isotherm}

The frequency response of the three higher concentrations $\left(1 \times 10^{-1}\right.$ up to $1 \times 10^{-3} \mathrm{M} 2$-MBT $)$ was fitted to the Langmuir kinetic model (Eq. 2). These concentrations were chosen because 2-MBT adsorption presents a well-defined exponential behavior (Figs. 2-4).

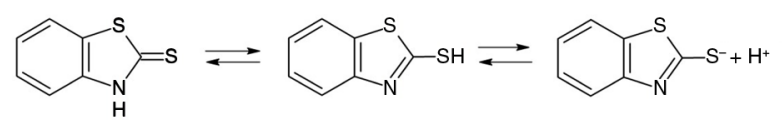

Figure 8. Thiol-Thione tautomeric equilibrium (Oshawa and Süetaka, 1979). 
The fitted curves are presented in Figs. 9-11 and their respective calculated parameters are shown in Table 1.

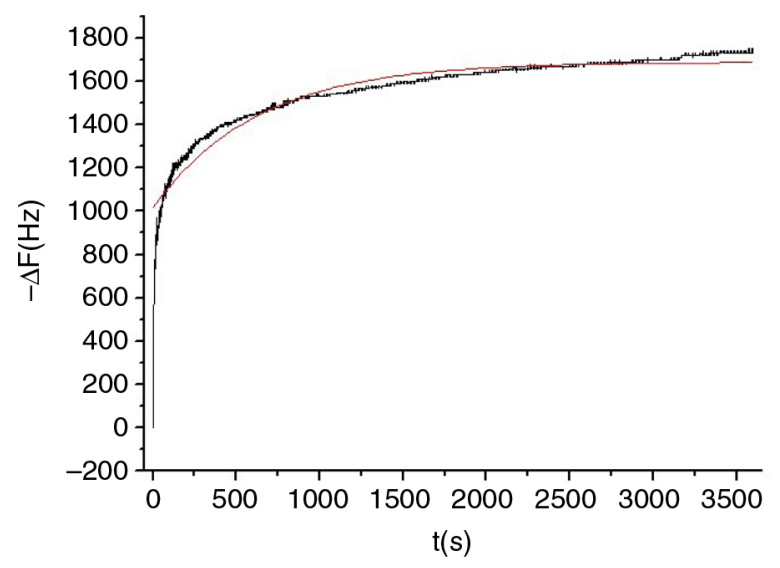

FIGURE 9. Fit of frequency response data to Langmuir adsorption isotherm (Eq. 2) of $1 \times 10^{-1} \mathrm{M} 2-\mathrm{MBT}$ on copper.

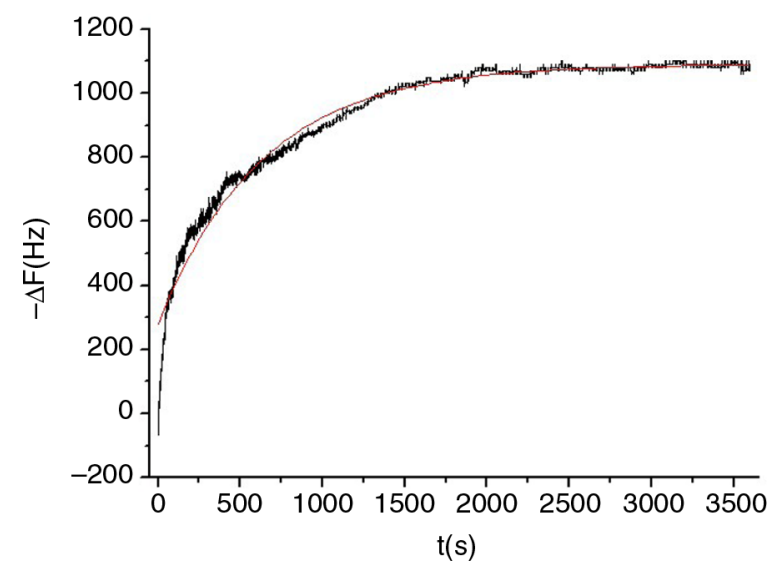

FIGURE 10. Fit of frequency response data to Langmuir adsorption isotherm (Eq. 2) of $1 \times 10^{-2} \mathrm{M} 2$-MBT on copper.

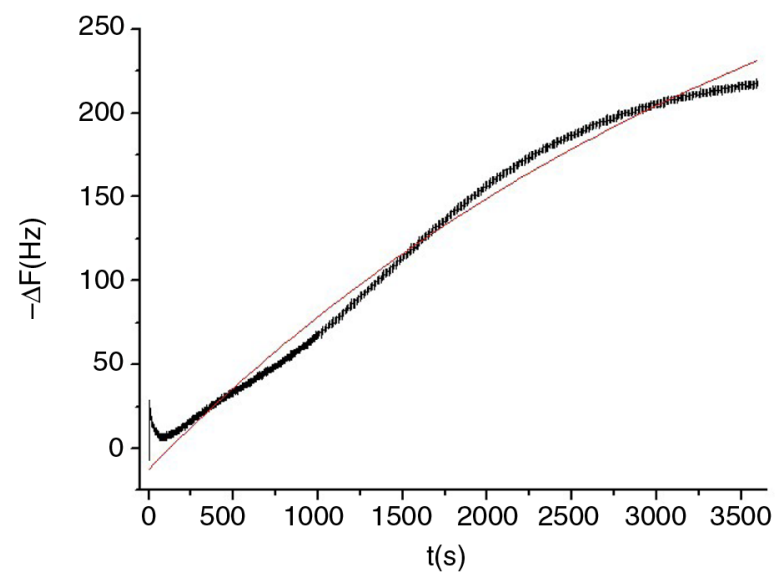

FiguRE 11. Fit of frequency response data to Langmuir adsorption isotherm (Eq. 2) of $1 \times 10^{-3} \mathrm{M}$ 2-MBT on copper.
TABLE 1. Langmuir fit parameters as a function of 2-MBT concentration [M]

\begin{tabular}{lcrcc}
\hline $\mathbf{2 - M B T}(\mathbf{M})$ & $\mathbf{R}^{\mathbf{2}}$ & \multicolumn{1}{c}{$\mathbf{K}^{\prime}$} & $\mathbf{k}_{\mathbf{m}}\left(\mathbf{s}^{-\mathbf{1}}\right)$ & \multicolumn{1}{c}{$\mathbf{t}_{\mathbf{0}}(\mathbf{s})$} \\
\hline $1 \times 10^{-1}$ & 0.91 & 1689.40 & $1.60 \times 10^{-3}$ & -575.94 \\
$1 \times 10^{-2}$ & 0.97 & 1090.64 & $1.58 \times 10^{-3}$ & -186.56 \\
$1 \times 10^{-3}$ & 0.98 & 399.53 & $2.48 \times 10^{-4}$ & 120.48 \\
\hline
\end{tabular}

The correlation coefficients show a very good agreement between the experimental data and the Langmuir isotherm. Figure 12 presents a plot of $k_{m}$ vs $C$ and its linear regression, which yields a $k_{a}$ value of $8.21 \times 10^{-3} \mathrm{M}^{-1} \mathrm{~s}^{-1}$ and a $k_{d}$ value of $8.38 \times 10^{-4} \mathrm{~s}^{-1}$.

Previously reported investigation (Karpovich and Blanchard, 1994) states that the negative deviation from linearity in the relation between $k_{m}$ and $C$ (for a thiol system, concentration range from $3 \times 10^{-6}$ to $3 \times 10^{-3} \mathrm{M}$ ) does not indicate that this system is illdescribed by the Langmuir adsorption model. This fact only shows the intrinsic limits to this treatment of a complex equilibrium process. In other words, for low adsorbent concentration, the system remains in close proximity to equilibrium and the expected mass change for such conditions lies beneath our limit of detection.

\subsection{Fraction of surface coverage $(\theta)$ and free energy of adsorption $\left(\Delta G_{a d s}\right)$}

According to equations 4 and 5, the equilibrium constant for 2-MBT adsorption process is $K_{e q}=9.79$, and the fraction of surface coverage $(\theta)$ values, as a function of adsorbent concentration, are shown in Table 2.

The free energy of adsorption was found to be $-5.59 \mathrm{~kJ} \mathrm{~mol}^{-1}$. It is considered that a chemisorbed molecule must have a free energy of $-40 \mathrm{~kJ} \mathrm{~mol}^{-1}$ (Atkins, 1999). Thus, the $\Delta G_{a d s}$ energy found for

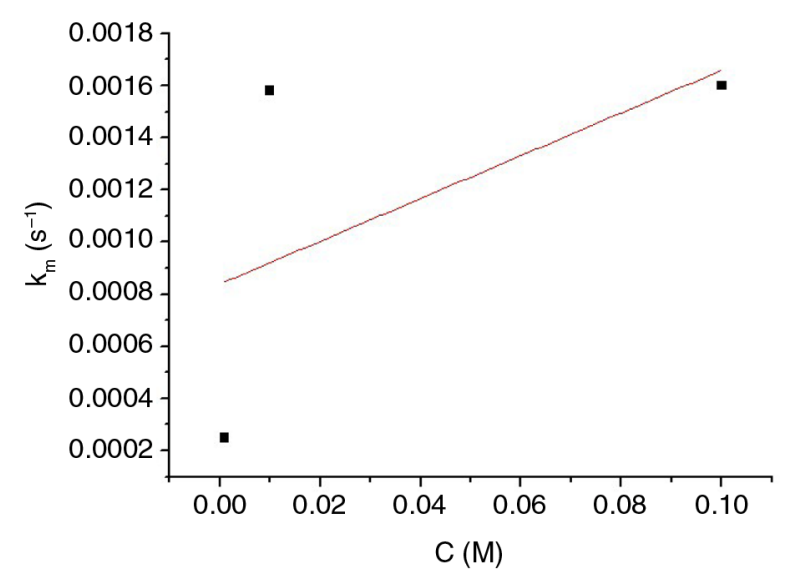

FIGURE 12. Linear fit for the concentration dependence of $k_{m}$. 
TABLE 2. Fraction of surface coverage of copper surface

\begin{tabular}{lc}
\hline $\mathbf{2 - M B T}(\mathbf{M})$ & $\theta$ \\
\hline $1 \times 10^{-1}$ & 0.50 \\
$1 \times 10^{-2}$ & 0.09 \\
$1 \times 10^{-3}$ & 0.01
\end{tabular}

2-MBT on copper surface clearly indicates that the adsorption is of physical nature, probably electrostatic.

\section{CONCLUSIONS}

2-MBT adsorbs on copper following the Langmuir adsorption isotherm. The initial desorption process observed in the concentration range $1 \times 10^{-3}$ to $1 \times 10^{-6} \mathrm{M}$ is probably due to water molecules being substituted by 2-MBT molecules at the metal surface. The kinetic parameters of 2-MBT adsorption process showed a very low rate in the range of $2.48 \times 10^{-4}$ to $1.60 \times 10^{-3} \mathrm{~s}^{-1}$ and low surface coverage of 0.01 to 0.50 . These facts are probably due to the lack of aggressive ions, which can deteriorate the copper patina, forming copper cations and exposing a pure metal surface to 2-MBT. Copper cations make possible the interaction with the anionic form of 2-MBT, leading to strong interactions, obtaining as a consequence higher adsorption rate and better surface coverage. Our research results showed that the calculated free energy of adsorption $\left(-5.59 \mathrm{~kJ} \mathrm{~mol}^{-1}\right)$ corresponds to a physisorption process, probably of electrostatic nature for the interaction between 2-MBT and copper surface in aqueous solution.

\section{ACKNOWLEDGMENTS}

The authors would like to express their gratitude to the Mexican Council of Science and Technology (CONACYT), grant 179110, for the financial support of this study.

\section{REFERENCES}

Aballe, A., Bethencourt, M., Botana, F.J., Marcos, M., Pérez, J., Rodríguez, M.A. (1997). Inhibidores de escaso impacto ambiental. Sistemas basados en tierras raras. Rev. Metal. 33 (6), 363-369. http://dx.doi.org/10.3989/revmetalm.1997. v33.i6.770.

Allam, N.K., Nazer, A.A. Ashour, E.A. (2009). A review of the effects of bezotriazole on the corrosion of copper and copper alloys in clean and polluted environments. $J$. Appl. Electrochem. 39, 961-969. http://dx.doi.org/10.1007/ s10800-009-9779-4

Antonijevic, M.M., Petrovic, M.B. (2008). Copper Corrosion Inhibitors. A review. Int. J. Electrochem. Sci. 3, 1-28.

Atkins, P.W. (1999). Physical Chemistry. Oxford University Press, pp. 857-858.

Behpour, M., Mohammadi, N. (2012). Investigation of inhibition properties of aromatic thiol self-assembled monolayer for corrosion protection. Corros. Sci. 65, 331-339. http:// dx.doi.org/10.1016/j.corsci.2012.08.036.
Chadwick, D., Hashemi, T. (1979). Electron spectroscopy of corrosion inhibitors: Surface films formed by 2-mercaptobenzothiazole and 2-mercaptobenzimidazole on copper. Surf. Sci. 89 (1-3), 649-659. http://dx.doi.org/10.1016/ 0039-6028(79)90646-0.

Davis, J.R. (2001). ASM Specialty Handbook: Copper and Copper Alloys. ASM International.

Eickes, C., Rosenmund, J., Wasle, S., Doblhofer, K., Wang, K., Weil, K.G. (2000). The electrochemical quartz crystal microbalance (EQCM) in the studies of complex electrochemical reactions. Electrochim. Acta 45 (22-23), 3623-3628. http:// dx.doi.org/10.1016/S0013-4686(00)00445-X.

Finšgar, M., Merl, D.K. (2014). An electrochemical, long-term immersion, and XPS study of 2-mercaptobenzothiazole as a copper corrosion inhibitor in chloride solution. Corros. Sci. 83, 164-175. http://dx.doi.org/10.1016/j.corsci.2014. 02.016 .

Godínez, L.A., Meas, Y., Ortega-Borges, R., Corona, A. (2003). Los inhibidores de corrosión. Rev. Metal. 39 (2), 140-158. http://dx.doi.org/10.3989/revmetalm.2003.v39.i2.325.

Haerifar, M., Azizian, S. (2013). An exponential kinetic model for adsorption at solid/solution interface. Chem. Eng. J. 215-216, 65-71. http://dx.doi.org/10.1016/j.cej.2012. 11.017

Jakeria, M.R., Fazal, M.A., Haseeb, A.S.M.A. (2015). Effect of corrosion inhibitors on corrosiveness of palm biodiesel. Corros. Eng. Sci. Techn. 50 (1), 56-62. http://dx.doi.org/10. 1179/1743278214Y.0000000208.

Jing, P., Hou, M., Zhao, P., Tang, X., Wan, H. (2013). Adsorption of 2-mercaptobenzothiazole from aqueous solution by organo-bentonite. J. Environ. Sci. 25 (6), 1139-1144. http://dx.doi.org/10.1016/S1001-0742(12)60166-1.

Karpovich, D.S., Blanchard, G.J. (1994). Direct Measurement of the Adsorption Kinetics of Alkanethiolate Self-Assembled Monolayers on a Microcrystalline Gold Surface. Langmuir 10 (9), 3315-3322. http://dx.doi.org/10.1021/la00021a066.

Kazansky, L.P., Selyaninov, I.A., Kuznetsov, Y.I. (2012). Adsorption of 2-mercaptobenzothiazole on copper surface from phosphate solutions. Appl. Surf. Sci. 258 (18), 6807-6813. http://dx doi.org/10.1016/j. apsusc 2012.03.097.

Kern, P., Landolt, D. (2001). Adsorption of organic corrosion inhibitors on iron in the active and passive state. A replacement reaction between inhibitor and water studied with the rotating quartz crystal microbalance. Electrochim. Acta 47 (4), 589-598. http://dx.doi.org/10.1016/S0013-4686 (01)00781-2.

Khaled, K.F., Fadl-Allah, S.A., Hammouti, B. (2009). Some benzotriazole derivatives as corrosion inhibitors for copper in acidic medium: Experimental and quantum chemical molecular dynamics approach. Mater. Chem. Phys. 117 (1), 148-155. http://dx.doi.org/10.1016/j.matchemphys.2009. 05.043 .

Kokalj, A., Peljhan, S., Finšgar, M., Milošev, I. (2010). What Determines the Inhibition Effectiveness of ATA, BTAH, and BTAOH Corrosion Inhibitors on Copper? J. Am. Chem. Soc. 132 (46), 16657-16668. http://dx.doi.org/10.1021/ ja107704y.

Langmuir, I. (1918). The adsorption of gases on plane surfaces of glass, mica and platinum. J. Am. Chem. Soc. 40 (9), 1361-1403. http://dx.doi.org/10.1021/ja02242a004

Marconato, J.C., Bulhões, L.O., Temperini, M.L. (1998). A spectroelectrochemical study of the inhibition of the electrode process on copper by 2-mercaptobenzothiazole in ethanolic solutions. Electrochim. Acta 43 (7), 771-780. http:// dx.doi.org/10.1016/S0013-4686(97)00204-1.

Marczewski, A.W. (2010). Analysis of Kinetic Langmuir Model. Part I: Integrated Kinetic Langmuir Equation (IKL): A New Complete Analytical Solution of the Langmuir Rate Equation. Langmuir 26 (19), 15229-15238. http://dx.doi. org/10.1021/la1010049.

Morales-Gil, P., Walczack, M.S., Cottis, R.A., Romero, J.M., Lindsay, R. (2014). Corrosion inhibitor binding in an acidic medium: Interaction of 2-mercaptobenizmidazole with carbon-steel in hydrochloric acid. Corros. Sci. 85, 109-114. http://dx.doi.org/10.1016/j.corsci.2014. 04.003 . 
Oshawa, M., Süetaka, W. (1979). Spectro-electrochemical studies of the corrosion inhibition of copper by mercaptobenzothiazole. Corros. Sci. 19 (7), 709-722. http://dx.doi.org/ 10.1016/S0010-938X(79)80069-4

Pan, Y.C., Wen, Y., Guo X.Y., Song, P., Shen, S., Du, Y.P., Yang, H.F. (2013). 2-Amino-5-(4-pyridinyl)-1,3,4-thiadiazole monolayers on copper surface: Observation of the relationship between its corrosion inhibition and adsorption structure. Corros. Sci. 73, 274-280. http://dx.doi.org/ 10.1016/j.corsci.2013.04.016

Quraishi, M.A., Jamal, D. (2001). Corrosion inhibition by fatty acid oxadiazoles for oil well steel $(\mathrm{N}-80)$ and mild steel. Mater. Chem. Phys. 71 (2), 202-205. http://dx.doi. org/10.1016/S0254-0584(00)00378-3.

Ramenzanzadeh, B., Arman, S.Y., Mehdipour, M., Markhali, B.P. (2014). Analysis of electrochemical noise (ECN) data in time and frequency domain for comparison corrosion inhibition of some azole compounds on $\mathrm{Cu}$ in $1.0 \mathrm{M} \mathrm{H}_{2} \mathrm{SO}_{4}$ solution. Appl. Surf. Sci. 289, 129-140. http://dx.doi.org/10.1016/j. apsusc.2013.10.119.

Schmitt, G. (1984). Application of Inhibitors for Acid Media: Report prepared for the European Federation of Corrosion Working Party on Inhibitors. Brit Corros. J. 19 (4), 165-176. http://dx.doi.org/10.1179/000705984798273100.

Solmaz, R., Altunbas, E., Kardas, G. (2011). Adsorption and corrosion inhibition effect of 2-((5-mercapto-1,3,4-thiadiazol2-ylimino)methyl)phenol Schiff base on mild steel. Mater. Chem. Phys. 125 (3), 796-801. http://dx.doi.org/10.1016/j. matchemphys.2010.09.056.
Subramanian, R., Lakshminarayanan, V. (2000). A study of kinetics of adsorption of alkanethiols on gold using electrochemical impedance spectroscopy. Electrochim. Acta 45 (27), 4501-4509. http://dx.doi.org/10.1016/S0013-4686 (00)00512-0.

Subramanian, R., Lakshminarayanan, V. (2002). Effect of adsorption of some azoles on copper passivation in alkaline medium. Corros. Sci. 44 (3), 535-554. http://dx.doi.org/10.1016/ S0010-938X(01)00085-3.

Telegdi, J., Shaban, A., Kálmán, E. (2000). EQCM study of copper and iron corrosion inhibition in presence of organic inhibitors and biocides. Electrochim. Acta 45 (22-23), 3639-3647. http://dx.doi.org/10.1016/S0013-4686(00)00447-3.

Trabanelli, G., Carassiti, V. (1970). Advances in corrosion science and technology. Vol. 1, Fontana, M.G., Staehle, R.W. (Ed.), Plenum Press, New York, pp. 147-160.

Winkler, D.A., Breedon, M., Hughes, A.E., Burden, F.R., Barnard, A.S., Harvey, T.G., Cole, I. (2014). Towards Chromate-free corrosion inhibitors: structure-property models for organic alternatives. Green Chem. 16, 3349-3357. http://dx.doi.org/ 10.1039/C3GC42540A

Zhang, J., Zhang, Q., Ren, H., Zhao, W., Zhang, H. (2007). Inhibition performance of 2-mercaptobenzothiazole derivatives in $\mathrm{CO}_{2}$ saturated solution and its adsorption behavior at Fe surface. Appl. Surf. Sci. 253 (18), 7416-7422. http:// dx.doi.org/10.1016/j.apsusc.2007.03.035. 